\title{
Clinical effectiveness of peripheral nerve blocks with lidocaine and corticosteroid in patients with trigeminal neuralgia
}

\author{
Trigeminal nevraljili hastalarda lidokain ve kortikosteroid kombinasyonuyla yapılan \\ periferik sinir bloklarının klinik etkinliği
}

Selin BALTA, ${ }^{\oplus G u ̈ l ~ K O ̈ K N E L ~ T A L U ² ~}$

\begin{abstract}
Summary
Objectives: Clinical efficacy of easily applicable peripheral nerve blocks has been in interest except open and closed surgical procedures requiring advanced equipment. We aimed to evaluate the clinical efficacy of triamcinolone and lidocaine injection for peripheral nerve branches in trigeminal neuralgia (TN) in terms of pain severity, pain frequency, and drug doses used. Methods: This study was a retrospective cohort study. A total of 72 patients with TN, who underwent peripheric trigeminal nerve injection with lidocaine and triamcinolone between 2011 and 2018, were included in the study. Pain severity, pain frequency, changes in carbamazepine (CBZ) equivalent doses, and pregabalin equivalent doses were evaluated. We also evaluated whether there was a correlation between the success of the procedure and independent variables.

Results: There was a statistically significant difference in pain intensity and frequency between baseline and post-procedure at 1,3 , and 6 months $(p=0.000)$. There was a statistically significant difference between CBZ equivalent doses at baseline, and 3 and 6 months after the procedure ( $p=0.002$ and 0.005 , respectively). Two complications were evaluated, one patient had prolonged painless paresthesia related to the procedure area lasting about 1 week and two patients had ecchymosis at the procedure area. Conclusion: The injection of lidocaine and corticosteroid combination for peripheral branches of the trigeminal nerve may result in short and mid-term clinical relief. Peripheral nerve blocks may be preferred for short-medium-term pain management with rare complications and simple device requirements also need little experience and skills.
\end{abstract}

Keywords: Facial pain; local anesthetic injection; peripheral nerve block; trigeminal neuralgia.

\section{Özet}

Amaç: Kolay uygulanabilir periferik sinir bloklarının klinik etkinliği, gelişmiş ekipman gerektiren açık ve kapalı cerrahi prosedürler haricinde ilgi konusudur. Trigeminal nevraljide periferik sinir dallarına triamsinolon ve lidokain enjeksiyon uygulamasının klinik etkinliğini ağrı şiddeti, ağrı sıklığı ve kullanılan ilaç dozları açısından değerlendirmeyi amaçladık.

Gereç ve Yöntem: Bu retrospektif kohort çalışmada 2011-2018 yılları arasında lidokain ve triamsinolon ile periferik trigeminal sinir bloğu yapılan trigeminal nevraljili 72 hastanın sonuçları değerlendirildi. Ağrı şiddeti, ağrı sıklığı, karbamazepin ile pregabalin eşdeğer dozlarının işlem öncesine göre işlem sonrası 1, 3 ve 6 . aylardaki sonuçları değerlendirildi. Ayrıca işlem başarısı ile bağımsız değişkenler arasında bir korelasyon olup olmadığını değerlendirildi.

Bulgular: İşlem öncesi ağıı şiddeti ve ağıı sıklığı değerleri ile işlem sonrası 1, 3 ve 6. aylar arasında istatistiksel olarak anlamlı bir fark vardı $(p=0.000)$. İslem öncesi karbamazepin eşdeğer dozları ile işlem sonrası 3 ve 6 . aydaki değerler arasında istatistiksel olarak anlamlı bir fark vardı (sırasıyla $p=0.002,0.005$ ). Retrospektif analizde, bir hastada işlem alanına bağlı olarak yaklaşık bir hafta süren ağrısız parestezi ve iki hastada işlem bölgesinde ekimoz gelişmiş olduğu saptandı.

Sonuç: Trigeminal sinirin periferik dallarına lidokain ve kortikosteroid enjeksiyonu ile kısa ve orta vadede klinik rahatlama sağlanabilir. Periferik sinir blokları, nadir görülen komplikasyonları kısa-orta vadede ağrı tedavisi için tercih edilebilir.

Anahtar sözcükler: Yüz ağrısı; lokal anestezi; periferik sinir blokajı; trigeminal nevralji

\footnotetext{
'Department of Algology, Konya Training and Research Hospital University of Health Sciences, Konya, Turkey

${ }^{2}$ Division of Algology, Department of Anestesiology and Reanimation, İstanbul University İstanbul Faculty of Medicine, Konya, Turkey

Submitted (Başvuru tarihi) 20.09.2020 Accepted after revision (Düzeltme sonrası kabul tarihi) 25.01.2021 Available online date (Online yayımlanma tarihi) 05.02.2021
}

Correspondence: Dr. Selin Balta. 1ağlık Bilimleri Üniversitesi, Konya Eğitim ve Araştırma Hastanesi, Algoloji Kliniği, Konya, Turkey.

Phone: +90 - 532 - 5002333 e-mail: selinaa01@yahoo.com

(C) 2021 Turkish Society of Algology 


\section{Introduction}

Trigeminal Neuralgia (TN) is characterized by paroxysmal intense, sharp, and electric-shock like pain with recurrent episodes localized at the innervation dermatomes of the trigeminal nerve. The episodes can be triggered with tactile stimulation and facial activities such as chewing, tooth brushing, laughing, and even talking and last for a few seconds to 2 minutes. Furthermore, there may be additional constant background facial pain. ${ }^{[1]}$ The pain predominantly occurs unilaterally, afflicts more often in the right side, female gender, mandibular, and/or maxillary trigeminal branches. ${ }^{[2]}$ The estimated lifetime prevalence of TN in a population-based study was $0.3 \%$. ${ }^{[3]}$ In TN, demyelination often develops as a result of compression of the nerve roots at the pons level. TN may also develop as a result of infiltrative or demyelinating diseases. There is a group of patients whose etiology cannot be elucidated despite all further investigations and evaluations. ${ }^{[4]}$

Carbamazepine (CBZ) and oxcarbazepine (OXC) are the first-line recommended medications in many clinical guidelines, reduce pain in most patients. ${ }^{[5]}$ Although these drugs are effective in $80 \%$ of patients at the beginning of treatment, there is a need to increase the dose due to autoinduction in half of the patients in the following periods. ${ }^{[6]}$ The common side effects of these drugs are fatigue, sleep, concentration, cognitive and attention impairment, mood changes, and even calcium metabolism disorder. ${ }^{[7]}$ Options such as microvascular decompression (MVD), percutaneous rad ofrequency rh zotomy, percutaneous glycerol rh zotomy, percutaneous balloon compress on, and gamma kn fe rad osurgery are ava lable for pat ents who are refractory to pharmacotherap es.

Barker et al. ${ }^{[8]}$ rev ewed 1336 MVD operat ons and reported trans ent fac al palsy, permanent hear ng loss, fac al numbness, and cerebrosp nal flu d fistula as compl cat ons. Carotid artery puncture, trigeminal depressor response, brainstem hematoma, corneal anesthesia, masseter weakness, diplopia, hearing and olfactory disturbances, cranial 3, 4, and 6 palsies, herpes simplex labialis, meningitidis, anesthesia dolorosa, dysesthesia, masticatory weakness, cerebrospinal fistula, and intracranial hemorrhage were reported as complications of the percutaneous techniques. ${ }^{[9]}$
Clinical efficacy of easily applicable peripheral nerve blocks has been in interest except open and closed surgical procedures requiring advanced equipment. ${ }^{[5,9]}$ We aimed to evaluate the clinical efficacy of trigeminal nerve peripheral branch injection in terms of pain severity, frequency, and drug doses at 6-month follow-up.

\section{Material and Methods}

\section{Patients}

After approval of the local ethics committee (Ethics Committee of Clinical Research, Istanbul University School of Istanbul Medicine 2018/352) patients who were referred to our clinic with the diagnosis of TN, who were over 18 years of age, who had a normal neurological examination of trigeminal nerve sensory and motor areas, and who underwent peripheral nerve block with lidocaine and triamcinolone combination between 2011 and 2018 were scanned. Who were unresponsive or could not tolerate the pharmacological treatments evaluated. Those who underwent an interventional procedure for TN for 6 months before the peripheral blocks of trigeminal nerves, patients who have started or increased their dose of carbamazepine, oxcarbazepine, pregabalin, gabapentin, baclofen, antidepressants during the follow-up period, those who were administered and those who had interventional procedures for head and neck pain were excluded from the study.

\section{Interventional Procedure}

Patients who were treated with supraorbital nerve for V1, infraorbital nerve for $\mathrm{V} 2$, and mental nerve for $\mathrm{V} 3$ were evaluated in accordance with the patient's clinical complaints. After foramen areas were identifed by palpation, the skin was cleaned with an antiseptic solution and advanced up to the needle periosteum (Gimon, AG, Germany) with 22 GX50 mm (Stimuplex UltraHNS 12 with SENSe ${ }^{\oplus}$; B Braun) needle 0.3. The procedure was performed ultrasound- guided also confrmed by $0.5 \mathrm{~mA}$ stimulation and negative blood aspiration. $0.25 \mathrm{ml}$ of $2 \%$ lidocaine and $10 \mathrm{mg}$ triamcinolone with a total volume of $0.5 \mathrm{ml}$ were injected per peripheral nerve.

A $50 \%$ or more decrease in pain severity that evaluated with VAS $(0-100 \mathrm{~mm})$ from baseline to followup periods at 1, 3, and 6 months was considered as clinical improvement. Changes in pain severity, pain 
frequency ( $<1$ week, 1-2 times a week, many times a week, 1-2 times a day, and many times a day, continuous classification used in the routine patient followup file of our clinic is used), carbamazepine equivalent doses ${ }^{[10]}$ and pregabalin equivalent doses ${ }^{[11]}$ were evaluated. In addition, existance of correlation between the success of the procedure at first and third months and independent variables was evaluated.

\section{Statistics}

Data analysis was performed using SPSS version 20.0 (IBM corporation, Somers, NY, USA). The Shapiro-Wilk and Kolmogorov-Smirnov tests were used to test the hypothesis of normal distribution. Non-normal distributions were summarized as medians, minimummaximum values. Categorical data were summarized as numbers and percentages. Kurtosis and skewness values of pain severity, pain frequency, pregabalin equivalent dose, carbamazepine equivalent dose values were not within the range of $-1,5-+1,5 .^{[12]}$ Kolmogorov-Smirnov and Shapiro-Wilk tests were $p<0.05$. Statistical analysis of the non-normal data of the patient was performed by nonparametric tests. Variables with non-normal distribution and continuous categorical variables were analyzed with Friedman's analysis. Wilcoxon rank-sum tests were conducted to compare changes pain severity, pain frequency, pregabalin equivalent dose, carbamazepine equivalent dose from baseline to after the intervention 1, 3 , and 6. months. Bonferroni correction was used to avoid possible type 1 error. An enter (likelihood ratio) binary logistic regression model for clinical success was constructed using the variables age, duration of disease, pain severity at baseline, and pain frequency at baseline. Univariate logistic regression analysis performed separately for each independent variable with the binary dependent variable was performed.

Missing value analysis was evaluated. Since the EM estimates statistics of the missing data were $p<0.05$, no loss data was assigned. Statistical analysis was performed with the available data.

\section{Results}

Patients who underwent peripheral nerve block with lidocaine and triamcinolone combination between 2011-2018 were scanned $(n=114)$. Who were unresponsive or could not tolerate the pharmacological treatments evaluated $(n=110)$. Those who
Table 1. Pain severity, pregabalin equivalent and carbamazepine equivalent dose at baseline and follow-up periods

\begin{tabular}{lcc}
\hline & Min.-Max. & Median \\
\hline Pain severity & & \\
$\quad$ Baseline & $70.0-100.0$ & 90.0 \\
1. month & $0.0-80.0$ & 0.0 \\
3. months & $0.0-100.0$ & 0.0 \\
6. months & $0.0-100.0$ & 0.0 \\
Pregabalin equivalent dose & & \\
Baseline & $0.0-600.0$ & 150.0 \\
3. months & $0.0-600.0$ & 150.0 \\
6. months & $0.0-600.0$ & 150.0 \\
Carbamazepine & & \\
equivalent dose & & \\
Baseline & $0.0-1200.0$ & 800.0 \\
3. months & $0.0-1200.0$ & 600.0 \\
6. months & $0.0-1200.0$ & 600.0 \\
\hline
\end{tabular}

Min.: Minimum; Max.: Maximum.

underwent an interventional procedure for TN for 6 months before the peripheral blocks of trigeminal nerves $(n=2)$, patients who have started or increased their dose of carbamazepine, oxcarbazepine, pregabalin, gabapentin, baclofen, antidepressants during the follow-up period $(n=32)$, those who were administered $(n=3)$ and those who had interventional procedures for head and neck pain $(n=1)$ were excluded from the study. 72 patients were included in the study. $58.3 \%$ of the patients were female $(n=42)$ and $41.7 \%(n=30)$ were male. V1 nerve, V2 nerve, V3 nerve, combination of $\mathrm{V} 1+\mathrm{V} 2$ nerves, combination of $\mathrm{V} 2+\mathrm{V} 3$ nerves, combination of $\mathrm{V} 1+\mathrm{V} 2+\mathrm{V} 3$ nerves were symptomatic and the percentages of them were $1.4 \%(n=1), 27.8 \%(n=20), 27.8 \%(n=20), 6.9 \%$ $(n=5), 33.3 \%(n=24), 2.8 \%(n=2)$ respectively. The symptom side was $62.5 \%(n=45)$ on the right, $36.1 \%$ $(n=26)$ on the left and $1.4 \%$ bilateral $(n=1)$. The average of $d$ sease durat on was 33.3 (3.0-63.0) months.

In this retrospective analysis $66.6 \%(n=48)$ patients had been followed for 3 months and $37.5 \%(n=27)$ had been followed for 6 months.

Pain severity values of the patients at baseline, 1, 3, and 6 months after the procedure were showed at Table 1. First, Friedman's analysis was evaluated, there was a statistically significant difference between the 
Table 2. Pain frequencies at baseline and follow-up periods

\begin{tabular}{|c|c|c|c|c|c|c|c|c|}
\hline \multirow{3}{*}{ Pain frequency } & \multicolumn{8}{|c|}{ Percentages (frequencies) } \\
\hline & \multicolumn{2}{|c|}{ Baseline } & \multicolumn{2}{|c|}{ 1. month } & \multicolumn{2}{|c|}{ 3. months } & \multicolumn{2}{|c|}{ 6. months } \\
\hline & $\%$ & $\mathbf{n}$ & $\%$ & $\mathbf{n}$ & $\%$ & $\mathbf{n}$ & $\%$ & $\mathbf{n}$ \\
\hline Continuous & 30.6 & 22 & 4.2 & 3 & 4.2 & 3 & 1.4 & 1 \\
\hline Many times a day & 55.6 & 40 & 16.7 & 12 & 22.2 & 12 & 5.6 & 4 \\
\hline $1-2$ times a day & 9.7 & 7 & 18.1 & 13 & 4.2 & 3 & 8.3 & 6 \\
\hline Many times a week & 2.8 & 2 & 4.2 & 3 & 1.4 & 3 & 21.4 & 1 \\
\hline 1-2 times a week & 1.4 & 1 & 2.8 & 2 & 1.4 & 2 & 0.0 & 0 \\
\hline Less than once a week & 0.0 & 0 & 0.0 & 0 & 0.0 & 0 & 0.0 & 0 \\
\hline $1-2$ times a month & 0.0 & 0 & 54.2 & 39 & 33.3 & 39 & 20.8 & 15 \\
\hline
\end{tabular}

groups $(p=0.000)\left(R^{2}=58.084\right)$. Wilcoxon signed-rank test was used to analyze the groups. There was a statistically significant difference between the severity of pain before and after 1 month, before and after 3 . months, and before and 6 . months ( $p$ values $=0.000$ ) and $Z$ values (effect sizes) were -6.801 (0.802), - 5.449 (0.642), and -4.295 (0.506).

The numbers and percentages of the pain frequency at baseline, 1, 3, and 6 months are shown in Table 2 . Friedman's analysis was evaluated, there was a statistically significant difference between repetitive measurements $(p=0.000)\left(R^{2}=57.457\right)$. The pairwise group comparison was evaluated with the Wilcoxon signed-rank test. There was a statistically significant difference between baseline and 1. months, baseline and 3. months, baseline and 6 . month values $(p=0.000$, and $Z$ values (effect sizes) were -6.459 (0.761), -4.884 (0.575), -4.045 (0.477), respectively).

The pregabalin equivalent dose mean values at baseline, 3, and 6 months after the procedure are shown in Table 1. There was a statistically significant difference between repeated measures by Friedman's analysis $(p=0.005)\left(R^{2}=10.571\right)$. The pairwise group comparison was evaluated with the Wilcoxon signed-rank test. There was a statistically significant difference between pretreatment and 3. months, pretreatment and 6 months after treatment $(p=0.004$, and 0.017 respectively) ( $Z$ values (effect sizes) -2.879 (0.339), -2.392 (0.282) respectively).

CBZ equivalent dose values at baseline, 3 , and 6 months after the procedure are shown in Table 1.
There was a statistically significant difference between repeated measures by Friedman's analysis $(p=0.005)\left(R^{2}=15.273\right)$. The pairwise group comparison was evaluated with the Wilcoxon signed-rank test There was a statistically significant difference between pretreatment and 3. months, pretreatment, and 6 . months ( $p=0.002$ and 0.005 respectively) and $Z$ values (effect sizes) -3.072 (0.362) and -2.840 (0.334) respectively.

In the present study, the effect size values were large for the decrease in pain severity at 1 month, moderate for a decrease in pain severity at 3 and 6 months, moderate for pain frequency at 1 and 6 months, decrease in pain frequency at 3 months and small for a decrease in carbamazepine equivalent and pregabalin equivalent doses at 3 and 6 months.

When the success of the procedure was considered as a $50 \%$ or more reduction in pain severity, $79.2 \%$ $(n=57), 33.3 \%(n=24), 24.6 \%(n=19)$ of the procedures were successful at 1, 3 and 6 months respectively.

The relationships between the success of the procedure at 1. month and the dependent variables which that age, disease duration, baseline pain intensity, baseline pain frequency was evaluated by binary logistic regression analysis $(p=0.750,0.900,0.142$, 0.991 respectively) (odds ratio $=1.007,1.018,0.965$, 1.000 respectively).

The relationships between the success of the procedure at 3. month and the dependent variables which that age, disease duration, baseline pain intensity, 
baseline pain frequency was evaluated by binary logistic regression analysis $(p=0.780,0.804,0.741$, 0.920 respectively) (odds ratio $=1.004,1.001,1.007$, 1.000 respectively).

The relationships between the success of the procedure at 6 . month and the dependent variables which that age, disease duration, baseline pain intensity, baseline pain frequency were evaluated by binary logistic regression analysis $(p=0.824,0.389,0.459$, 0.995 respectively) (odds ratio $=1.007,1.008,1.027$, 0.000 respectively).

Complications were evaluated, 1 patient had prolonged painless paresthesia related to the procedure area lasting about 1 week and 2 patients had ecchymosis at the procedure area.

\section{Discussion}

In this study peripheral trigeminal nerve blocks were found to be effective in relieving pain severity, and frequency for short and intermediate periods. Also, peripheral nerve blocks have a dose-reducing effect on carbamazepine, oxcarbazepine, and gabapentinoids for up to 6 months after the procedure in patients with TN. Peripheral nerve blocks were found to be safe when evaluated in terms of complications and side effects. Similar results have been shown in the case series in which peripheral nerve blocks were evaluated in 3-9 patients with TN, consistent with the clinical efficacy that may extend up to 6 month. ${ }^{[13-15]}$ Stani et al. ${ }^{[16]}$ demonstrated that the combination of lidocaine injection for the peripheral branches of the trigeminal nerve with pharmacological therapy was superior to pharmacological therapy in the short term follow-up. Bainton et al. ${ }^{[17]}$ showed a prolonged clinical response of peripheral nerve blocks was associated with neurotoxicity of local anesthetics. Neurotoxicity was explained by increased perineurial permeability, and endoneurial fluid pressure, by axonal injury. Bainton et al. ${ }^{[17]}$ showed the neurotoxicity of local anesthetics in their electrophysiological study by compound action potential reduction and long-term conduction block.

In the present study, the combination of local anesthetic with corticosteroid was evaluated. Eker et al. ${ }^{[18]}$ demonstrated that corticosteroid addition to local anesthetic in short-term follow-up in patients with TN provides superiority in clinical efficacy. It has been shown that corticosteroids may be effective on pain by inhibiting proinflammatory cytokine synthesis $^{[19]}$ and that corticosteroid addition provides more effective and long-lasting clinical efficacy in blocks and infusions. ${ }^{[20]}$

In the present study, there was no correlation between clinical efficacy and age, disease duration, baseline pain intensity, baseline pain frequency. Han et al. ${ }^{[21]}$ showed that a short duration of disease was positively correlated with treatment efficacy for trigeminal nerve block in patients with TN. Consistent with the literature, our study also showed that peripheral nerve injections were safe in terms of side effects and complications. ${ }^{[13-16]}$

One of the limitations of our study is its retrospective design. Prospective randomized controlled studies with long-term follow-up may clarify the clinical efcacy of peripheral nerve blocks in TN and help to identify the factors realted with clinical success.

Peripheral nerve blocks help pain relief in patients with TN who were unresponsive or could not tolerate to the pharmacological treatments. Furthermore, peripheral nerve blocks requiring less experience and skills with rare complications, and simple devices requirement.

Financial Disclosure: This research received no specific grant from any funding agency in the public, commercial, or not-for-profit sectors.

\section{Conflict-of-interest issues regarding the authorship or article: None declared.}

\section{Peer-rewiew: Externally peer-reviewed.}

\section{References}

1. Gronseth G, Cruccu G, Alksne J, Argoff C, Brainin M, Burchiel $\mathrm{K}$, et al. Practice parameter: the diagnostic evaluation and treatment of trigeminal neuralgia (an evidence-based review): Report of the quality standards subcommittee of the american academy of neurology and the european federation of neurological societies. Neurology 2008;71(15):1183-90. [CrossRef]

2. Maarbjerg S, Gozalov A, Olesen J, Bendtsen L. Trigeminal neuralgia-a prospective systematic study of clinical characteristics in 158 patients. Headache 2014;54(10):1574-82.

3. Mueller $D$, Obermann $M$, Yoon MS, Poitz F, Hansen $N$, Slomke MA, et al. Prevalence of trigeminal neuralgia and persistent idiopathic facial pain: a population-based study. 
Cephalalgia 2011;31(15):1542-8. [CrossRef]

4. Love $S$, Coakham HB. Trigeminal neuralgia: pathology and pathogenesis. Brain 2001;124(12):2347-60. [CrossRef]

5. Cruccu G, Gronseth G, Alksne J, Argoff C, Brainin M, Burchiel $\mathrm{K}$, et al. AAN-EFNS guidelines on trigeminal neuralgia management. Eur J Neurol 2008;15(10):1013-28. [CrossRef]

6. Campbell F, Graham J, Zilkha K. Clinical trial of carbazepine (tegretol) in trigeminal neuralgia. J Neurol Neurosurg Psychiatry 1966;29(3):265-7. [CrossRef]

7. Besi E, Boniface D, Cregg R, Zakrzewska J. Comparison of tolerability and adverse symptoms in oxcarbazepine and carbamazepine in the treatment of trigeminal neuralgia and neuralgiform headaches using the liverpool adverse events profile (AEP). J Headache Pain 2015;16(1):563. [CrossRef]

8. Barker FG, Jannetta PJ, Bissonette DJ, Larkins MV, Jho HD. The long-term outcome of microvascular decompression for trigeminal neuralgia. N Engl J Med 1996;334(17):107783. [CrossRef]

9. Raj PP, Lou L, Erdine S, Staats PS, Waldman SD, Racz G, et al. Interventional Pain Management: Image-Guided Procedures. Philedelphia, PA: Somatic Blocks of the Head; 2008.

10. Albani F, Grassi B, Ferrara R, Turrini R, Baruzzi A, Group PS. Immediate (overnight) switching from carbamazepine to oxcarbazepine monotherapy is equivalent to a progressive switch. Seizure 2004;13(4):254-63. [CrossRef]

11. Toth C. Substitution of gabapentin therapy with pregabalin therapy in neuropathic pain due to peripheral neuropathy. Pain Med 2010;11(3):456-65. [CrossRef]

12. Tabachnick BG, Fidell LS. Using Multivariate Statistics. New York: Harper Collins; 2012.

13. Perloff MD, Chung JS. Urgent care peripheral nerve blocks for refractory trigeminal neuralgia. Am J Emerg Med 2018;36(11):2058-60. [CrossRef]

14. Choi YK, Liu J. The use of $5 \%$ lidocaine for prolonged analgesia in chronic pain patients: A new technique. Reg Anesth Pain Med 1998;23(1):96-100. [CrossRef]

15. Goto F, Ishizaki K, Yoshikawa D, Obata H, Arii H, Terada M. The long lasting effects of peripheral nerve blocks for trigeminal neuralgia using high concentration of tetracaine dissolved in bupivacaine. Pain 1999;79(1):101-3. [CrossRef]

16. Stani FD, Ojango C, Dugoni D, Lorenzo LD, Masala S, Delfini $\mathrm{R}$, et al. Combination of pharmacotherapy and lidocaine analgesic block of the peripheral trigeminal branches for trigeminal neuralgia: A pilot study. Arq Neuropsiquiatr 2015;73(8):660-4. [CrossRef]

17. Bainton CR, Strichartz GR. Concentration dependence of lidocaine-induced irreversible conduction loss in frog nerve. Anesthesiology 1994;81(3):657-67. [CrossRef]

18. Eker HE, Cok OY, Aribogan A, Arslan G. Management of neuropathic pain with methylprednisolone at the site of nerve injury. Pain Med 2012;13(3):443-51. [CrossRef]

19. Li H, Xie W, Strong JA, Zhang JM. Systemic antiinflammatory corticosteroid reduces mechanical pain behavior, sympathetic sprouting, and elevation of proinflammatory cytokines in a rat model of neuropathic pain. Anesthesiology 2007;107(3):469-77. [CrossRef]

20. Varrassi G, Paladini A, Marinangeli F, Racz G. Neural modulation by blocks and infusions. Pain Pract 2006;6(1):34-8.

21. Han KR, Kim C, Chae Y, Kim DW. Efficacy and safety of high concentration lidocaine for trigeminal nerve block in patients with trigeminal neuralgia. Int J Clin Pract 2008;62(2):248-54. [CrossRef] 